\section{Effect of Salicylic Acid on the Gene Transcript and Protein Accumulation of Flavonoid Biosynthesis-related Enzymes in Vitis vinifera Cell Suspension Cultures}

\author{
Huiling Wang ${ }^{1}$ \\ Beijing Academy of Forestry and Pomology Sciences, Beijing 100097, \\ China; and Key Laboratory of Urban Agriculture (North China), Ministry \\ of Agriculture, People's Republic of China
}

Wei Wang ${ }^{1}$

Key Laboratory of Silviculture of the State Forestry Administration, The Institute of Forestry, The Chinese Academy of Forestry, Yi He Yuan Hou, Beijing 100091, China

Weidong Huang
College of Food Science and Nutritional Engineering, China Agricultural
University, Beijing 100083, China

Haiying $\mathbf{X u}^{2}$

Beijing Academy of Forestry and Pomology Sciences, Beijing 100097, China; and Beijing Engineering Research Center for Deciduous Fruit Trees, Beijing 100097, China

Additional index words. grape, anthocyanins, proanthocyanidins, paclobutrazol, protein accumulation

\begin{abstract}
Salicylic acid (SA) as a plant signal molecule plays an important regulatory role in stimulating the accumulation of plants' defensive compounds. Numerous studies have shown its regulating effects on the biosynthesis of flavonoids. However, the controlling mechanism needs to be made clear further. Here, Vitis vinifera L. 'Cabernet Sauvignon' cell suspension cultures were treated with $\mathrm{SA}$ and its synthesis inhibitor paclobutrazol (Pac) to investigate their effects on flavonoid biosynthesis. The accumulation of gene transcripts and proteins of flavonoid biosynthesis pathway enzymes, including chalcone synthase ( $V v C H S)$, chalcone isomerase ( $V v C H I)$, dihydroflavonol 4-reductase ( $V v D F R)$, and anthocyanidin synthase ( $V v A N S)$, were detected using real-time polymerase chain reaction (RT-PCR), quantitative polymerase chain reaction (qPCR), and westernblotting techniques. The results showed that treatment with exogenous SA at the proper concentration enhanced the production of flavonoids such as anthocyanins and proanthocyanidins (PAs) inside the suspension-cultured cells. The induction of anthocyanins and PAs was found to be time course-dependent. The mRNA and protein accumulation of $V v C H S, V v C H I, V v D F R$, and $V v A N S$ in the treatment system were enhanced too, and the changes were observed concomitantly. Treatment of Pac inhibited the induction of the accumulation of gene transcripts and proteins in accordance with the decreased accumulation of flavonoids. These results suggest that exogenous $\mathrm{SA}$ could induce both transcript and protein accumulation of flavonoid biosynthesis-related enzymes and in turn enhance the accumulation of flavonoid compounds such as anthocyanins and PAs in suspension-cultured grape cells.
\end{abstract}

Received for publication 22 Sept. 2017. Accepted for publication 26 Oct. 2017.

This research was supported by the special fund of the China Agriculture Research System (CARS-29), the National Natural Science Foundation of China (grant number 31601712), and the Natural Science Foundation of Beijing Academy of Agriculture and Forestry Sciences (No. QNJJ201604).

${ }^{1}$ These authors contributed equally to this work. ${ }^{2}$ Corresponding authors. E-mail: haiyingxu63@ sina.com orwhlhappy@aliyun.com. resistance, signaling in plant-microbe interactions, protection from ultraviolet radiation, and so on (Buer, 2010). So, the biosynthesis and regulation of flavonoids in grape have attracted more attention.

In grapevine, anthocyanins and PAs are the two major classes of flavonoids (Wang et al., 2010). The enzymes responsible for each catalytic step of the flavonoid biosynthetic pathway in grapevine have been well characterized (Petrussa et al., 2013, Fig. 1). The first key enzyme of flavonoid biosynthesis is $V v$ CHS [electrical conductivity (EC) 2.3.1.74], which catalyzes the stepwise condensation of three acetate moieties from malonyl-coenzyme A (CoA) with 4-coumaroylCoA to give $4,2^{\prime}, 4^{\prime}, 6^{\prime}$-tetrahydroxy-chalcone (Tian et al., 2006). Chalcone isomerase (EC 5.5.1.6) plays a major role in the cyclization reaction from chalcones to flavanones (Wang et al., 2012). Dihydroflavonol 4-reductase (EC 1.1.1.219), a "later" key enzyme, catalyzes the nicotinamide adenine dinucleotide phosphate-dependent conversion of stereospecific dihydroflavonols into unstable leucoanthocyanidins (Zhang et al., 2008); anthocyanidin synthase (EC 1.14.11.19) at the branch point converts the colorless leucoanthocyanidins to colored anthocyanidins (Wang et al., 2010).These four flavonoid biosynthesis-related genes can be regulated by several stresses, such as solar radiation (Matus et al., 2009), pathogens (Ahn et al., 2014; Kortekamp, 2006), and biotic or chemical elicitation including methyl jasmonate, polysaccharide, abscisic acid, and so on (D’Onofrio et al., 2009; Jeong et al., 2004; $\mathrm{Xu}$ et al., 2015).

Salicylic acid is a phenolic phytohormone, which has always been identified as

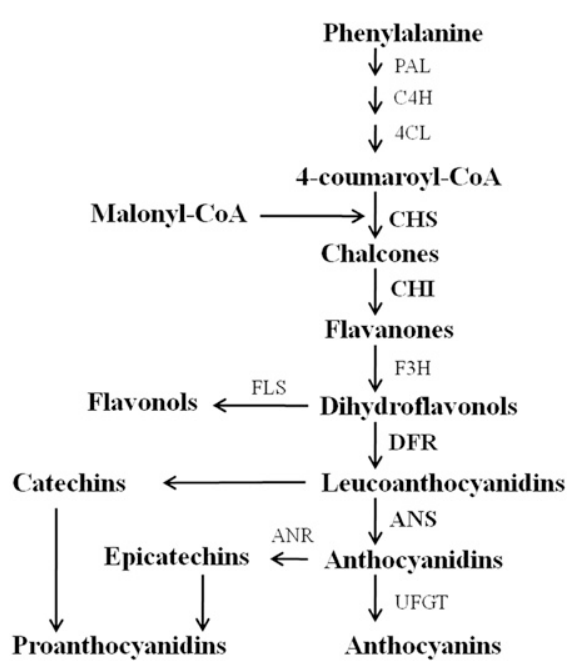
secondary metabolites in grape with an essential role in determining grape berry quality and wine characteristics such as color, flavor, astringency, and bitterness (Flamini et al., 2013). Many pharmacological activities including anticancer, anticarcinogenic, and antimicrobial properties have also been ascribed to these compounds (Georgiev et al., 2014). Additional evidence have also shown that flavonoids have vital functions in disease
Fig. 1. Schematic representation of the flavonoid biosynthesis pathway. PAL $=$ phenylalanine ammonia-lyase; $\mathrm{C} 4 \mathrm{H}=$ cinnamate-4-hydroxylase; $4 \mathrm{CL}=4$-coumarate: $\mathrm{CoA}$ ligase , $\mathrm{CHS}=$ chalcone synthase; $\mathrm{CHI}=$ chalcone isomerase; $\mathrm{F} 3 \mathrm{H}=$ flavanone-3-hydroxylase; FLS = flavonol synthase; DFR = dihydroflavonol reductase; ANS $=$ anthocyanidin synthase; ANR = anthocyanidin reductase; UFGT $=$ UDP-Glc:flavonoid 3-O-glucosyltransferase. 
a key signaling molecule involved in plant defense responses against stresses (An and Mou, 2011). Previous studies have shown that SA can enhance the accumulation of flavonoid compounds in many plants (Ahn et al., 2014; Dokhanieh et al., 2013; Ghasemzadeh et al., 2012; Pacheco et al., 2013; Thiruvengadam et al., 2015). However, the mechanism of SA-enhanced flavonoid accumulation needs to be made clear further. Sun et al. (2012) have found that the exogenous application of SA enhanced rutin accumulation and influenced the expression patterns of 4-coumaroyl CoA ligase (4CL), CHS, and flavanone 3-hydroxylase in Fagopyrum tataricum Gaertn leaves. Thiruvengadam et al. (2015) have pointed that chinese cabbage (Brassica rapa ssp. pekinensis) plants treated with exogenous SA showed significant increases in phenylalanine ammonialyase (PAL), CHI, flavonol synthase (FLS), and ANS gene expression, corresponding well to the enhancement of total flavonoid content. In grapevine, several authors have revealed that SA could improve the production of phenylpropanoids, stilbenes, anthocyanins, and flavonols and provokes changes in the gene expression related to the synthesis of flavonoids, such as $V v$ PAL, $V v \mathrm{CHS}, V v \mathrm{CHI}$, and stilbene synthase ( $V v$ STS) genes as well (Ahn et al., 2014; Chen et al., 2006; Xu et al., 2015). Although the studies mostly focused on the regulation of them at the transcript level, little was known about the regulation at the protein level. In addition, the relationships between SA and the downstream enzymes of flavonoid biosynthesis such as $V v \mathrm{DFR}$ and $V v$ ANS have not yet been reported in grapevine.

Paclobutrazol can significantly inhibit the activity of benzoic acid hydroxylase enzyme in the SA biosynthetic pathway (León et al., 1995), so it can be used as an effective candidate inhibitor for the synthesis of SA from phenylalanine (Liu et al., 2006). Plant cell suspension cultures have been considered as a convenient model for studying the regulation of secondary mechanisms (Mustafa et al., 2011). So in the present work, the effects of SA and its synthesis inhibitor Pac on flavonoids such as anthocyanins and PA accumulationwere investigated in $V$. vinifera cell suspension cultures. The relationships between SA and $V v \mathrm{CHS}, V v \mathrm{CHI}, V v \mathrm{DFR}$, and $V v$ ANS were investigated at both transcriptional and translational levels. The results will broaden our understanding of flavonoid regulation and provide academic evidences for the production of high-flavonoid grapes and wines.

\section{Materials and Methods}

Establishment and maintenance of cell suspensions. Grape callus was established from 'Cabernet Sauvignon' berries as described by Wang et al. (2015) and maintained on solid B5 medium (Gamborg et al., 1968) containing $3 \mathrm{~g} \cdot \mathrm{L}^{-1}$ phytagel, supplemented with $30 \mathrm{~g} \cdot \mathrm{L}^{-1}$ sucrose, $250 \mathrm{mg} \cdot \mathrm{L}^{-1}$ casein hydrolysate, $0.1 \mathrm{mg} \cdot \mathrm{L}^{-1}$ a-naphthylacetic acid, and
$0.2 \mathrm{mg} \cdot \mathrm{L}^{-1}$ kinetin, adjusted to $\mathrm{pH}$ 5.9. Grape cell suspension cultures were established by inoculating calli in $150-\mathrm{mL}$ flasks containing $60 \mathrm{~mL}$ of the same liquid medium without phytagel. The culture was kept at $25{ }^{\circ} \mathrm{C}$ with constant shaking (120 rpm) and received $16 \mathrm{~h}$ artificial daylight per day. For maintenance, the culture was diluted in fresh medium once a week by transferring $15 \mathrm{~mL}$ of cell cultures into $45 \mathrm{~mL}$ of fresh medium.

Exogenous $S A$ and Pac treatment in grape cell suspension cultures. Treatment of exogenous SA and its biosynthesis inhibitor Pac was performed in grape cell cultures at the $\log$ growth stage (Obinata et al., 2003, $\approx 5 \mathrm{~d}$ after subculture). SA and Pac solutions were added into cell cultures to yield final concentrations of 50,100, and $150 \mu \mathrm{M}$, respectively. The control cell cultures were treated with equal volumes of filter-sterilized methanol (final concentration was $0.2 \%, \mathrm{v} / \mathrm{v}$ ). The most effective concentration of SA for flavonoid synthesis was chosen based on the results. Cell cultures were incubated on a rotary shaker at $110 \mathrm{rpm}$ continuous light $(16,000$ LX) at $26 \pm 1{ }^{\circ} \mathrm{C}$ until they were sampled. Samples were collected at $0,0.5,1,2,4,6$, and $8 \mathrm{~d}$ after treatment by vacuum filtration. The harvested cells were rapidly washed, weighed to determine fresh weight $(\mathrm{FW})$,
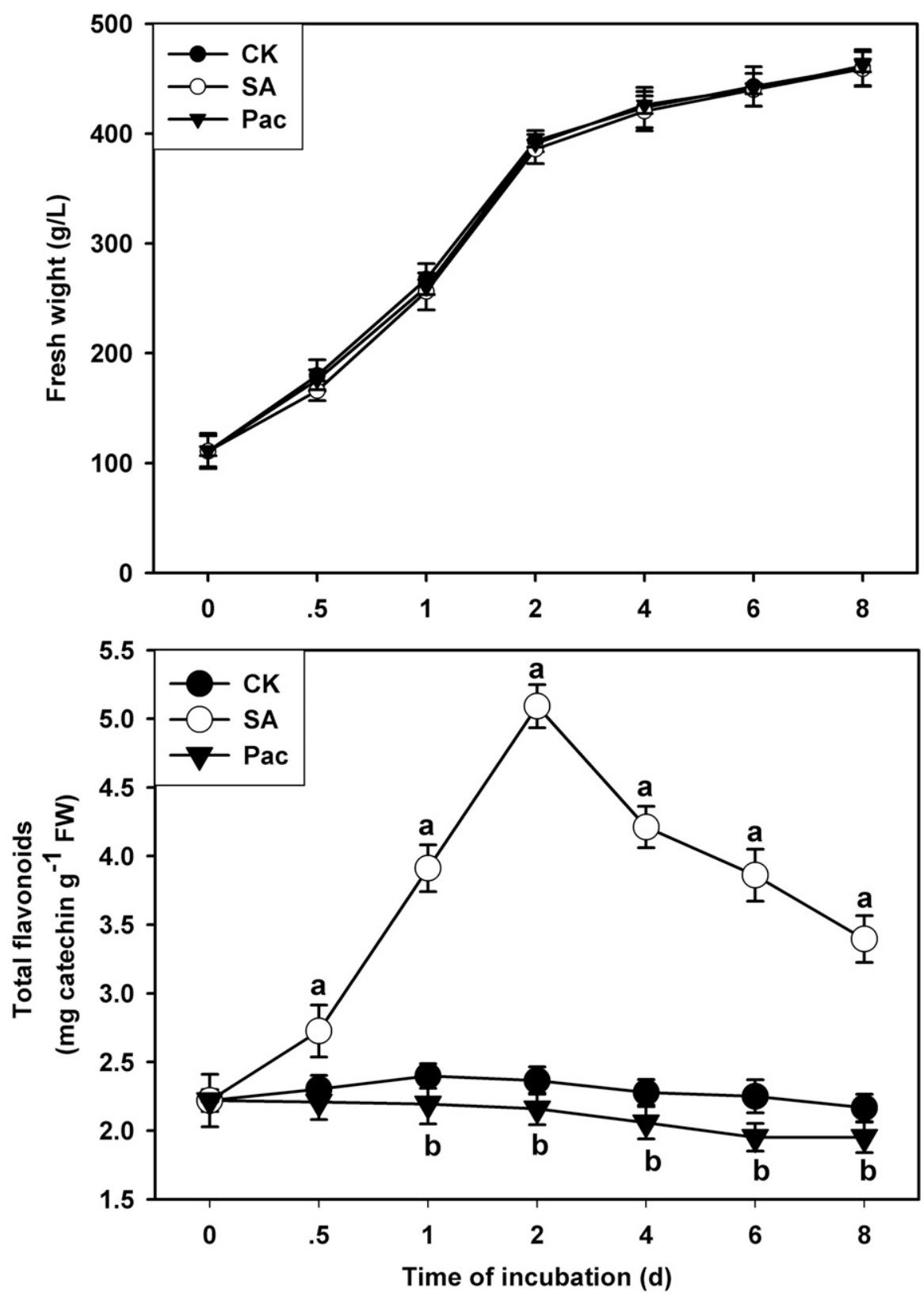

Fig. 2. Effects of salicylic acid (SA) and paclobutrazol (Pac) on cell growth and total flavonoid content in grape berry suspension cell cultures. The upper artwork shows the effects of $100 \mu \mathrm{M}$ SA and Pac on cell growth. The bottom artwork shows the effects of $100 \mu \mathrm{M} \mathrm{SA}$ and Pac on total flavonoid content. Bars are SES $(n=3)$. The small letters indicate the statistically significant difference (Student's $t$ test, $P<$ 0.05 ) between the data of different treatments: a, SA vs. the control; b, Pac vs. the control. FW $=$ fresh weight; $\mathrm{CK}=$ control. 
frozen in liquid nitrogen, and stored at $-80{ }^{\circ} \mathrm{C}$ until analysis. The treatment was performed using three biological replications.

Determination of total flavonoid, anthocyanin, and PA content. Total flavonoids in the collected cells were extracted using $2 \%$ hydrochloric acid in methanol for $24 \mathrm{~h}$ in the dark at $25{ }^{\circ} \mathrm{C}$. After centrifugation at $12,000 \mathrm{~g}$ for $15 \mathrm{~min}$ at $4{ }^{\circ} \mathrm{C}$, the supernatant was used to assay total flavonoids. Total flavonoids were measured in accordance with the methods described in Wolfe et al. (2003). Absorption was analyzed at $510 \mathrm{~nm}$ and the results were expressed as milligram of catechin equivalent per gram of $\mathrm{FW}$ ( $\mathrm{mg}$ catechin $/ \mathrm{g} \mathrm{FW}$ ).

Total anthocyanins were extracted from about $1 \mathrm{~g} \mathrm{FW}$ of cell powders according to the method of Boss et al. (1996). The content was quantified by spectrophotometric analysis. Absorbance was measured for each sample at $535 \mathrm{~nm}$. The results were expressed as OD535 per gram of FW (OD535/g FW).

Total PAs were extracted from $1 \mathrm{~g}$ cell samples according to Kennedy et al. (2000). The prepared samples were extracted twice with $20 \mathrm{~mL} \mathrm{70 \%} \mathrm{acetone} \mathrm{solution} \mathrm{(containing}$ $0.1 \%$ ascorbic acid) for $6 \mathrm{~h}$ at $25^{\circ} \mathrm{C}$ in the dark with occasional shaking. After centrifugation at $8000 \mathrm{rpm}$ for $15 \mathrm{~min}$, the combined supernatants were condensed by rotary evaporation and then $\mathrm{ddH}_{2} \mathrm{O}$ was added to a total volume of $50 \mathrm{~mL}$. The concentration of PAs was determined by the method of Reddy et al. (2007) using procyanidins as standard. The results were expressed as mg procyanidins/g FW. Three samples were drawn from each replication and measurements were taken for each sample.

$R N A$ preparation, $R T-P C R$, and quantitative real-time polymerase chain reaction ( $q R T-P C R$ ) analysis. Total RNA was isolated from cells using the CTAB method described by Wen et al. (2005). cDNA was prepared according to the manufacturer's instruction of avian myeloblastosis virus reverse transcriptase (Promega A3500; Promega, Madison, WI).

The mRNA expression patterns of the four selected genes including $V v C H S$, VvCHI, $V v D F R$, and $V v A N S$ were examined by RTPCR. Amplification of VvActinl cDNA was used as an internal control. Primer sequences were designed based on $V$. vinifera nucleotide sequences deposited in GenBank as shown in Supplemental Table 1. For each primer set, polymerase chain reaction (PCR) conditions were optimized for Tm using gradient PCR and optimized for the number of cycles by running the aforementioned PCR for 36 cycles and removing the reaction product every third cycle from cycles 15 to 36 to obtain the cycling parameters. The PCR products were detected and analyzed according to the method of Wang et al. (2011). For each sample, RNA was extracted twice and RT-PCR was performed at least three times.

In addition, RT-PCR was performed to analyze the relative expression of $V v C H S$, $V v C H I, V v D F R$, and $V v A N S$ at the most crucial time point ( $1 \mathrm{~d}$ after the treatments) according to the results of RT-PCR. Primer sequences were obtained from the literature as shown in Supplemental Table 2. Two-step qPCR was carried out in the CFX 96 RT-PCR system (Bio-Rad, Richmond, CA) using a SYBR PCR kit (Tiangen, Beijing, China). The qPCR cycling condition was as follows: $95^{\circ} \mathrm{C}$ for $10 \mathrm{~s}$, then 38 cycles of $95^{\circ} \mathrm{C}$ for $5 \mathrm{~s}$, annealing temperature for $30 \mathrm{~s}$, and $72{ }^{\circ} \mathrm{C}$ for $30 \mathrm{~s}$. The primers used in the qPCR analysis are given in Supplemental Table 2. Primer specificity and amplification efficiency were determined by melting curve analysis. Gene transcripts were quantified upon normalization to $V v$ Actin 1 by using the comparative cycle threshold method (i.e., comparing the cycle threshold of the target gene with that of
VvActin1). Normalized fold change in expression was calculated by using the $2^{-\Delta \Delta C t}$ method (Livak and Schmittgen, 2001). Gene expression was displayed as mean \pm SE calculated for three independent replications.

Protein extraction and western blotting analysis. Total proteins were extracted from sampled cells according to the method of Famiani et al. (2000) with modification. The extraction buffer consisted of $50 \mathrm{~mm}$ Tris$\mathrm{HCl}(\mathrm{pH} 8.9), 2 \%(\mathrm{w} / \mathrm{v})$ sodium dodecyl sulfate, $5 \mathrm{~mm}$ ascorbic acid, $5 \mathrm{~mm}$ ethylenediaminetetraacetic acid, $1 \mathrm{~mm}$ phenylmethylsulfonyl fluoride, $14 \mathrm{~mm} \beta$-mercaptoethanol, and $0.15 \%(\mathrm{w} / \mathrm{v})$ polyvinylpyrrolidone. Protein

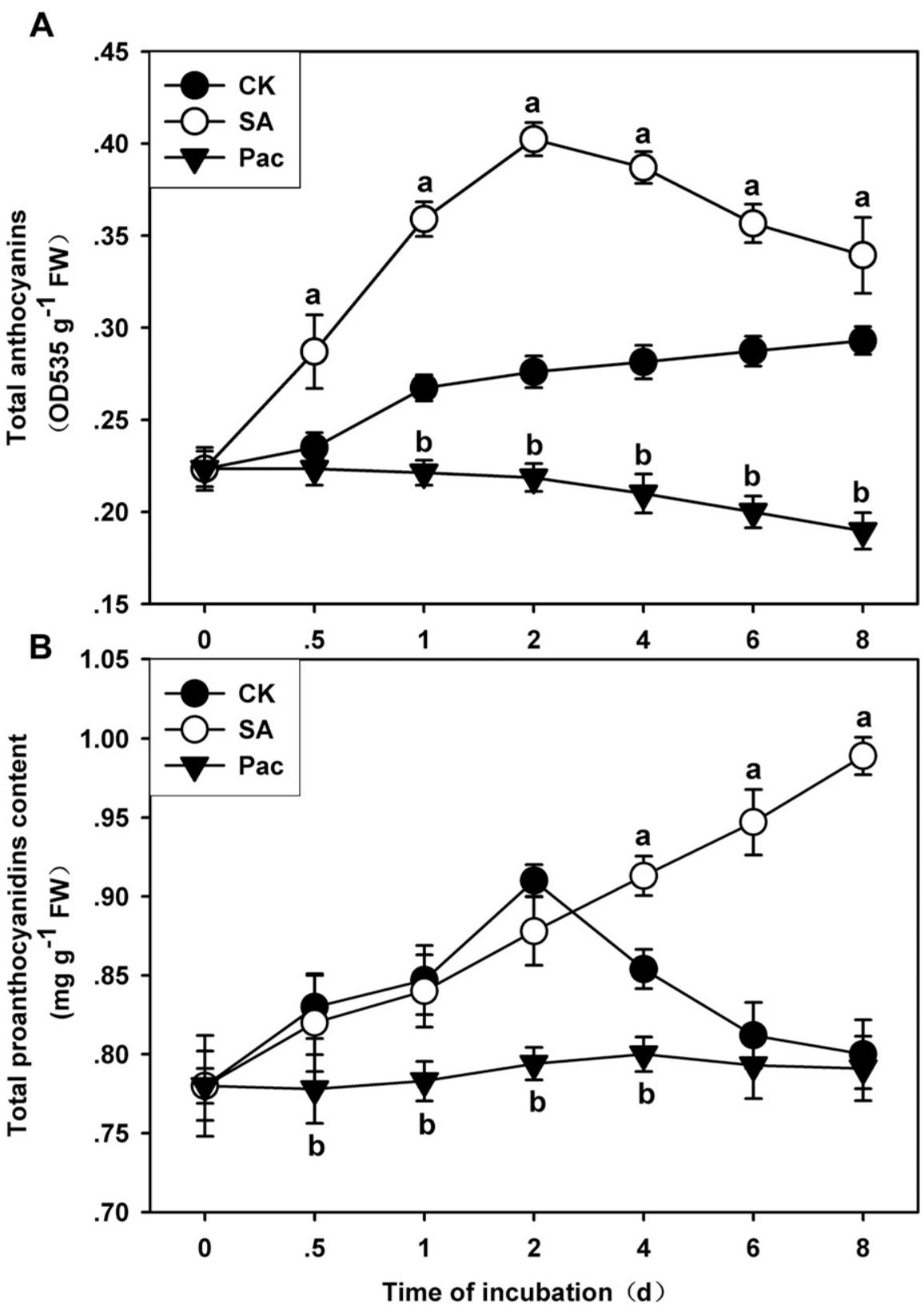

Fig. 3. Effects of salicylic acid (SA) and paclobutrazol (Pac) on total anthocyanin content and proanthocyanidin (PA) content in grape berry suspension cell cultures. (A) The effect of $100 \mu \mathrm{M}$ SA and Pac on total anthocyanin content; (B) The effect of $100 \mu \mathrm{M}$ SA and Pac on total PA content. Bars are ses $(n=3)$. The small letters indicate the statistically significant difference (Student's $t$ test, $P<$ 0.05 ) between the data of different treatments: a, SA vs. the control; b, Pac vs. the control. FW $=$ fresh weight; $\mathrm{CK}=$ control. 
concentration was determined as described in Bardford (1976) using bovine serum albumin as the standard.

The separation of total proteins was performed using sodium dodecyl sulfate polyacrylamide gel electrophoresis (SDS-PAGE) in $12 \%$ polyacrylamide gels as described by Laemmli (1970). An identical amount of total proteins $(10 \mu \mathrm{g} / \mathrm{lane})$ was separated using a Bio-Rad Mini electrophoresis system (Bio$\mathrm{Rad})$. After electrophoresis, the proteins were electro-transferred to nitrocellulose $(0.45 \mathrm{~mm}$, Amersham Life Science, Cleveland, $\mathrm{OH}$ ) using a transfer apparatus (Bio-Rad) as in Isla et al. (1998). Immunological detection of proteins on the NC membrane was carried out using primary polyclonal antibodies of $V v$ CHS (Tian et al. 2006), $V v$ CHI (Wang et al. 2012), $V v$ DFR (Zhang et al. 2008), and $V v$ ANS (Wang et al. 2010) in a $1 / 800(\mathrm{v} / \mathrm{v})$ dilution and alkaline phosphatase-conjugated antirabbit $\mathrm{IgG}$ antibody from goat (1/500 dilution; Sigma-Aldrich, St. Louis, MO) as a secondary antibody at $25^{\circ} \mathrm{C}$. Then, the membrane was stained with $10 \mathrm{~mL}$ of 5-bromo-4-chloro-3-indolyl phosphate/nitro blue tetrazolium in the dark, and the reaction was ended by using double distilled water. The intensity of immunoblotting signal was determined by using a densitometer.

Statistical analysis. All experiments were performed using three biological replications, and all measurements were analyzed in triplicate. The obtained data were expressed as mean \pm SE. Graphs of the experimental data were developed using Sigma plot 10.0 (Systat Inc., Point Richmond, CA) and Photoshop 7.0 (Adobe Systems, San Jose, CA) software. Statistical analysis was performed by analysis of variance using Student's $t$ test and Duncan's multiple range test, using SPSS version 13.0 (SPSS Inc., Chicago, IL).

\section{Results}

Effects of SA and Pac on the accumulation of total flavonoids in grape cell cultures. To investigate the effects of SA and its synthesis inhibitor Pac on flavonoid biosynthesis in grape cell cultures, the optimal concentrations were first confirmed. The cell growth and flavonoid content in the cells treated using four different final concentrations $(0$, 50,100 , and $150 \mu \mathrm{M}$ ) were detected. The cell growth of grape cell cultures was monitored by FW. As shown in Supplemental Fig. 1, the growth of cells treated with SA at 50 and 100 $\mu \mathrm{M}$ showed no significant difference from untreated cell cultures. However, SA at 150 $\mu \mathrm{M}$ caused a significant $\mathrm{FW}$ reduction. When the SA synthesis inhibitor Pac was at 50 and $100 \mu \mathrm{M}$, cell growth was unaffected, but 150 $\mu \mathrm{M}$ Pac treatments influenced the cells' regular growth (Supplemental Fig. 1).

Salicylic acid at various tested concentrations all induced flavonoid accumulation in cell cultures (Supplemental Fig. 2). However, when the SA concentration was at $100 \mu \mathrm{M}$, total flavonoid content showed maximum level at $2 \mathrm{~d}$ after incubation. Treatment of $100 \mu \mathrm{M}$ Pac reduced the flavonoid accumula- tion throughout the experiment (Supplemental Fig. 2). Therefore, $100 \mu \mathrm{M}$ was chosen as the optimal concentration of SA and Pac for in vivo incubation of grape cell cultures according to the preliminary experiment results.

The application of $100 \mu \mathrm{M}$ SA increased total flavonoid content in grape cell cultures within 0.5-2 $\mathrm{d}$ without influencing cell growth (Fig. 2). In addition, the total flavonoid content of cells treated with $100 \mu \mathrm{M}$ SA reached the maximum level at $2 \mathrm{~d}$ after incubation $(73.3 \%$ higher than in control cells), then decreased gradually within 4-8 d, and the content in 8-d treated cells was still higher than that in control cells. For cells incubated in $100 \mu \mathrm{M}$ Pac, cell growth was unaffected and the total flavonoid content gradually decreased with time (Fig. 2). The flavonoid content of control cells remained low and constant during the experimental period (Fig. 2).

Effects of SA and Pac on the accumulation of total anthocyanins and PAs in grape cell cultures. As shown in Fig. 3A, $100 \mu \mathrm{M}$ SA had an obvious effect on the accumulation of anthocyanins. Total anthocyanin contents began to increase at $0.5 \mathrm{~d}$ after SA treatment, with the maximum appearing $2 \mathrm{~d}$ after treatment and then decreasing. However, the total anthocyanin content was still higher than that of the control at even $8 \mathrm{~d}$ after treatment. Pac treatments markedly decreased the total anthocyanin content, reaching a minimum $(34.6 \%$ less than the control) at $8 \mathrm{~d}$ after treatment. In control cells, the accumulation of total anthocyanins increased slowly.
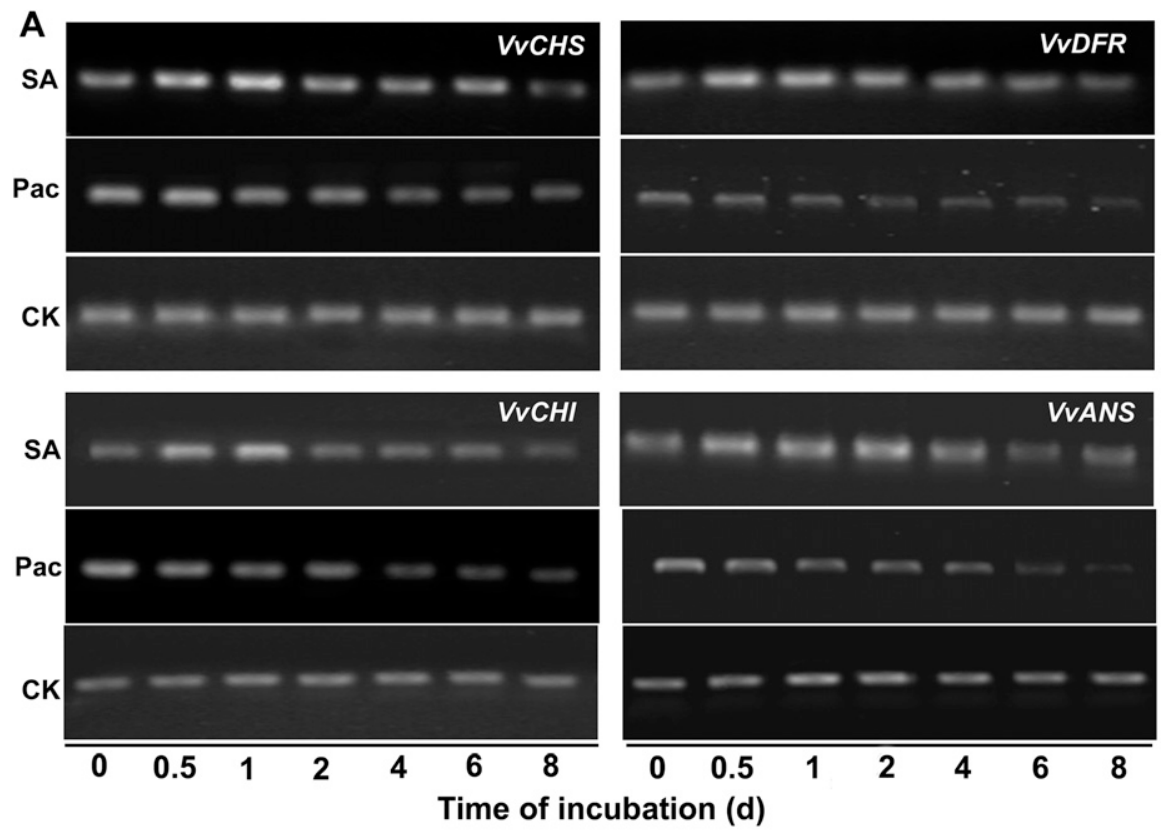

B

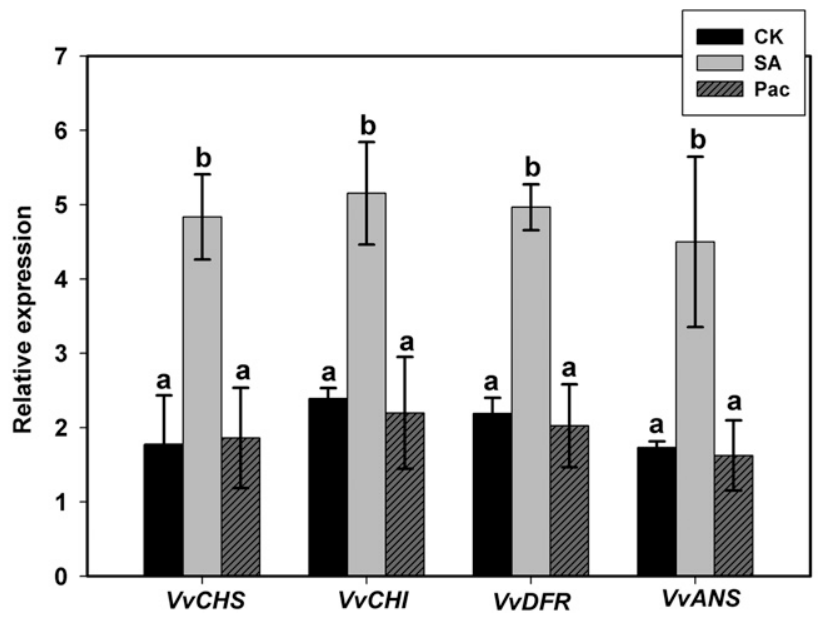

Fig. 4. Effects of salicylic acid (SA) and paclobutrazol (Pac) on the accumulation of gene transcript of $V v C H S, V v C H I, V v D F R$, and $V v A N S$ in grape berry suspension cell cultures. (A) The effects of SA and Pac on the accumulation of gene transcripts of $V v C H S, V v C H I, V v D F R$, and $V v A N S$ detected by realtime polymerase chain reaction. (B) The relative expression of $V v C H S, V v C H I, V v D F R$, and $V v A N S$ at $1 \mathrm{~d}$ of incubation of SA and Pac investigated by quantitative real-time polymerase chain reaction. Bars are SES $(n=3)$. The small letters indicate the statistically significant difference (Student's $t$ test, $P<0.05$ ) between the data of different treatments: a, SA vs. the control; $b, \mathrm{Pac}$ vs. the control. $V v \mathrm{CHS}=$ chalcone synthase; $V v \mathrm{CHI}=$ chalcone isomerase; $V v \mathrm{DFR}=$ dihydroflavonol 4-reductase; $V v \mathrm{ANS}=$ anthocyanidin synthase; $\mathrm{CK}=$ control. 
Treatment of exogenous SA $(100 \mu \mathrm{M})$ also enhanced total PA accumulation in grape cell cultures (Fig. 3B), although the PA content was lower than those in control cells $2 \mathrm{~d}$ before incubation. The changes in PA content (Fig. 3B) exhibited a gradual increase throughout the experimental period. After $2 \mathrm{~d}$, the gradually increasing content exceeded those in control cells until $8 \mathrm{~d}$ after treatment. No obvious changes in PA content were observed in the presence of Pac. In the control cells, a gradual increase in PA content was investigated at the early experimental period and then a decrease was observed within 2-8 d.

Effects of $S A$ and Pac on the mRNA accumulation of genes related to flavonoid biosynthesis in grape cell cultures. To evaluate the effect of SA and Pac on the flavonoid biosynthesis-related genes' mRNA level, the expression of $V v \mathrm{CHS}, V v \mathrm{CHI}, V v \mathrm{DFR}$, and $V v$ ANS in grape cells at different times after treatment was analyzed by RT-PCR. $V v A c$ $\operatorname{tin} 1$, which was expected to show a constitutive expression pattern, was used as the control (Supplemental Fig. 3). As shown in Fig. 4, the changes in transcript accumulation of these four genes showed similar trends after SA elicitation. The rapid accumulation of $V v C H S, V v C H I, V v D F R$, and $V v A N S$ mRNA in response to SA was observed. The increase in the transcription of $V v C H S$ and $V v C H I$ began to appear at $0.5 \mathrm{~d}$ after SA treatment and attained a maximum at $1 \mathrm{~d}$.
From $2 \mathrm{~d}$ after incubation, the $V v C H S$ and $V v C H I$ mRNA levels decreased apparently (Fig. 4A). As for $V v D F R$, the mRNA level peaked at $0.5 \mathrm{~d}$ after SA incubation and then decreased gradually, but was still higher than that of the control (Fig. 4A). The transcript accumulation of $V v A N S$ increased gradually to the maximum at $2 \mathrm{~d}$ and then declined (Fig. 4A). All the results indicated that the transcriptions of $V v \mathrm{CHS}, V v \mathrm{CHI}, V v \mathrm{DFR}$, and $V v$ ANS genes were enhanced by SA treatment. In Pac-treated cells, transcript accumulation of the four genes was inhibited obviously (Fig. 4A). There was no significant change in transcript accumulation in control cells along the treatment time course (Fig. 4A).

The qPCR analysis showed that the expression levels of $V v C H S$ and $V v C H I$ reached the peak at $1 \mathrm{~d}$ after SA incubation (2.74- and 2.15fold higher than that in untreated cells, respectively), whereas there was no difference in the expression levels of $\mathrm{VvCHS}$ and $\mathrm{VvCHI}$ between Pac-treated and control cells (Fig. 4B). The treatment of SA also induced relative higher expression levels of $V v D F R$ and $V v A N S$ at $1 \mathrm{~d}$ of incubation (2.27- and 2.59-fold higher than that in untreated cells, respectively). No significant change was observed in $V v D F R$ and $V v A N S$ expression levels between Pac-treated and control cells (Fig. 4B).

Effects of $S A$ and Pac on the protein accumulation of enzymes related to flavonoid biosynthesis in grape cell cultures. The changes in $V v \mathrm{CHS}, V v \mathrm{CHI}, V v \mathrm{DFR}$, and $V v$ ANS protein amounts in SA- or Pactreated cells were detected by western blotting (Figs. 5 and 6). Identical total proteins were separated by SDS-PAGE.

The results of the effects of SA on $V v \mathrm{CHS}$ protein amounts are shown in Fig. 5A. A 43$\mathrm{kDa}$ peptide was specifically detected with an antigrape CHS polyclonal antibody on SDSPAGE gel of the sampled cell crude protein extract, indicating that the $V v \mathrm{CHS}$ protein existed in both SA-treatment and control cells. $V v$ CHS protein amounts started to increase after the application of SA at $0.5 \mathrm{~d}$, reached a maximum at $1 \mathrm{~d}$, and then slightly decreased at $2 \mathrm{~d}$ (Fig. 5A). The immunoblotting signal in the SA-treated cells was stronger than that in the control cells (Fig. 5A) between 0.5 and $4 \mathrm{~d}$ of incubation. Application of Pac inhibited the amount of $V v \mathrm{CHS}$ protein accumulation (Fig. 5A). No comparable changes in $V v \mathrm{CHS}$ protein amount were observed in the control cells.

Figure $5 \mathrm{~B}$ shows that a $25-\mathrm{kDa}$ peptide was specifically detected with antigrape $\mathrm{CHI}$ polyclonal antibody in grape cell crude protein extract. Compared with the control, the immunoblotting signal in sampled cells at 0.5 and $1 \mathrm{~d}$ after SA treatment (Fig. 5B) was obviously stronger. After $2 \mathrm{~d}$, the immunoblotting signals were weakened (Fig. 5B). The immunoblotting signal in Pac-treated

A

VvCHS B

B

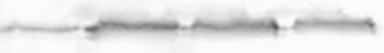

$=43 \mathrm{KDa}$

SA

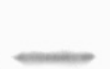

$\mathrm{VvCHI}$
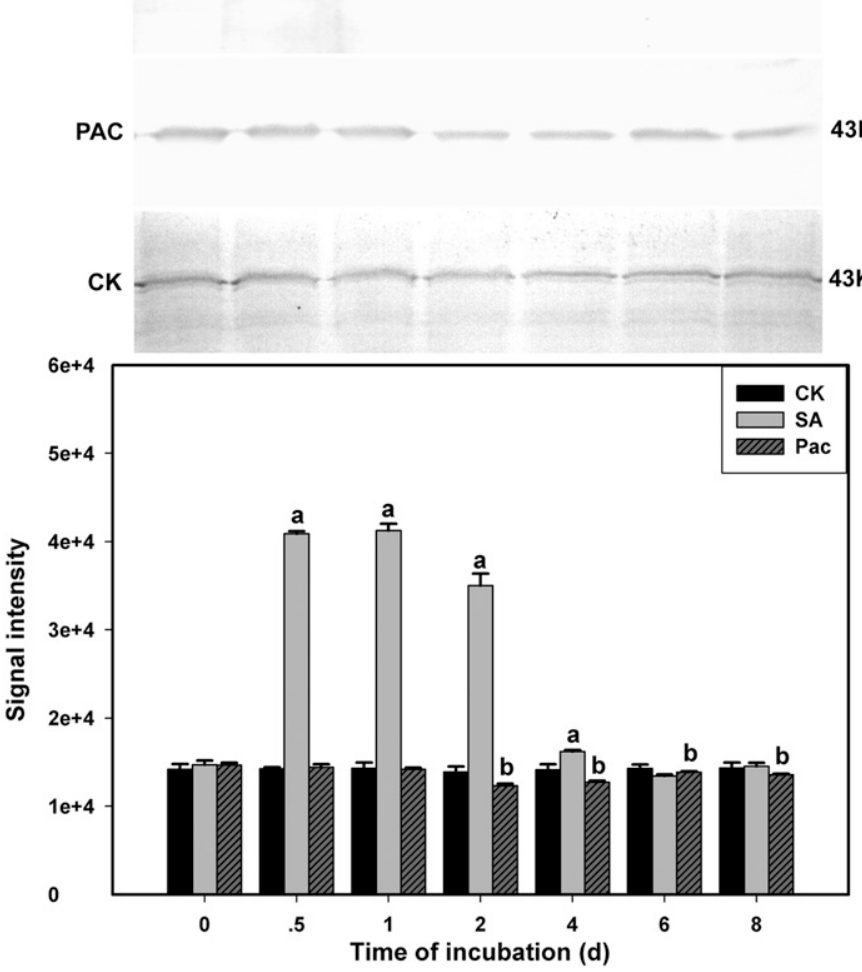

43KDa

43KDa

PAC
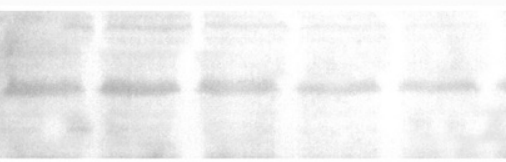

CK
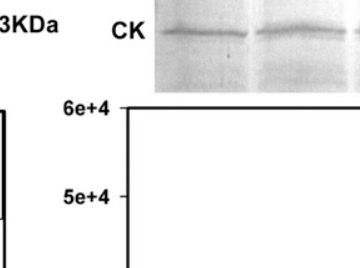

$\sqrt{2}$
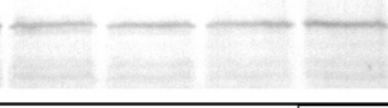

$25 \mathrm{KDa}$

$25 \mathrm{KDa}$

Fig. 5. Effects of salicylic acid (SA) and paclobutrazol (Pac) on the protein accumulation of chalcone synthase (A) and chalcone isomerase (B) in grape berry suspension cell cultures. The data of signal intensity are means from three analyses of one of two independent replications. Bars are sES $(n=3)$. The small letters indicate the statistically significant difference (Student's $t$ test, $P<0.05$ ) between the data of different treatments: a, SA vs. the control; b, Pac vs. the control. $\mathrm{CK}=$ control. 
A

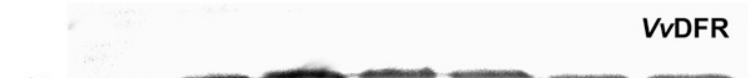

SA

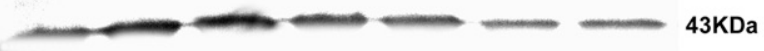

B

\section{(1)}

SA

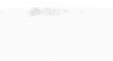

$-$

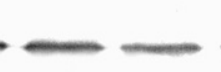

VvANS

40KDa

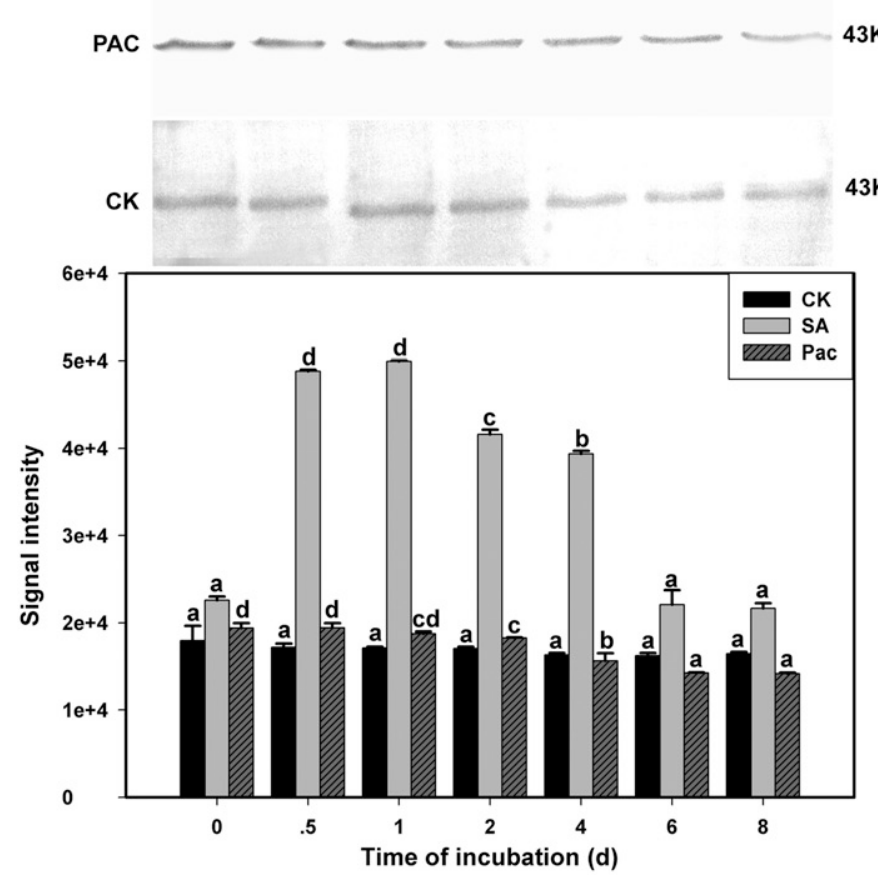

43KDa

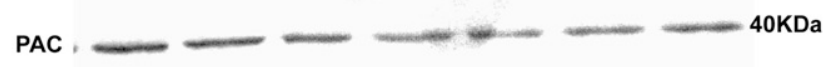

43KDa
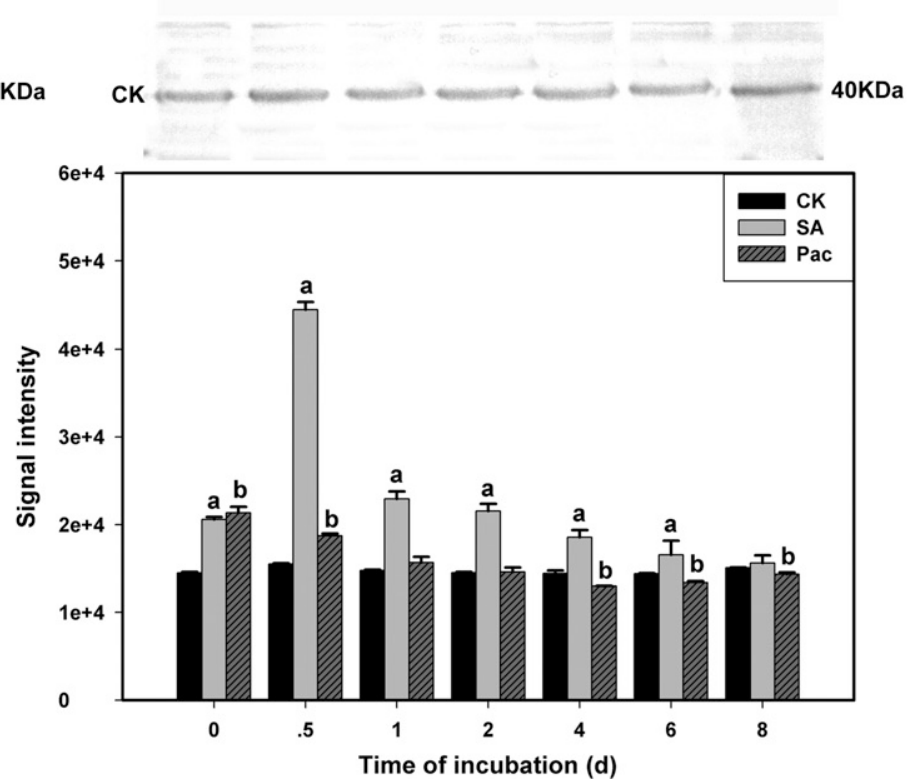

Fig. 6. Effects of salicylic acid (SA) and paclobutrazol (Pac) on the protein accumulation of dihydroflavonol 4-reductase (A) and anthocyanidin synthase (B) in grape berry suspension cell cultures. The data of signal intensity are means from three analyses of one of two independent replications. Bars are SES $(n=3)$. The small letters indicate the statistically significant difference (Student's $t$ test, $P<0.05$ ) between the data of different treatments: a, SA vs. the control; b, Pac vs. the control. $\mathrm{CK}=$ control.

cells showed a gradual decrease. No comparable change in the intensity of immunoblotting signal was detected in the control cells.

Treatment of exogenous SA $(100 \mu \mathrm{M})$ also enhanced protein accumulation of $V v$ DFR in grape cells. As shown in Fig. 6A, a single 43$\mathrm{kDa}$ polypeptide was detected specifically from the protein fractions of the samples with a polyclonal antibody raised against grape berry DFR. $V v$ DFR protein amounts began to increase after incubation of SA at $0.5 \mathrm{~d}$ and reached the maximum level at $1 \mathrm{~d}$, which was significantly higher than that in control cells. This was followed by a slight decrease, but the immunoblotting signal was still higher than that in the control (Fig. 6A). Application of Pac blocked new $V v$ DFR protein synthesis (Fig. 6A). There was a significant decrease in $V v$ DFR protein between Pac-treated and control cells.

A single polypeptide with a molecular mass of $\approx 40 \mathrm{kDa}$ was detected specifically from the protein fractions of the grape cells, using a polyclonal antibody raised against grape berry ANS (Fig. 6B). Maximum accumulation of $V v A N S$ protein occurred at $0.5 \mathrm{~d}$ after SA incubation and then decreased until the end of the period of measurement. But the immunoblotting signal was still significantly higher than that in controlled cells until $6 \mathrm{~d}$ of incubation. The addition of Pac inhibited the $V v$ ANS protein accumulation in grape cells. The protein accumulation levels of $V v$ ANS were significantly lower than that in control cells at the late time course (Fig. 6B).

\section{Discussion}

Salicylic acid is always considered as a plant signal molecule involved in stimulating the accumulation of plant defensive compounds and having positive regulating effects on the pathways of plant secondary metabolism, which yields a great variety of flavonoids with structural and defenserelated functions (Tounekti et al., 2013). However, intensive studies still need to be conducted to explore the relationship between SA and the flavonoid metabolic pathway in plants. In the present work, we observed the effects of SA on anthocyanin and PA production, and the expression of four important enzymes involved in flavonoid biosynthesis including $V v \mathrm{CHS}, V v \mathrm{CHI}$, $V v \mathrm{DFR}$, and $V v \mathrm{ANS}$ at both mRNA and protein levels. We found that the application of exogenous $100 \mu \mathrm{M}$ SA could enhance the biosynthesis of anthocyanins and PAs and actually induce both gene transcript and protein accumulation of $V v \mathrm{CHS}, V v \mathrm{CHI}, V v \mathrm{DFR}$, and $V v$ ANS, whereas the SA synthesis inhibitor Pac suppressed the mRNA and protein accumulation of the four enzymes, corresponding well to the decrease in flavonoid compound content.

Identifying the appropriate concentration of SA for enhancing flavonoid accumulation is important. For example, Pacheco et al. (2013) have observed a significantly higher total flavonoid content in Calendula officinalis $\mathrm{L}$. asteraceae inflorescences sprayed with $\mathrm{SA}$ at $1 \mathrm{~mm}$, whereas the biosynthesis of anthocyanin increased for Zingiber officinale Roscoe when $100 \mu \mathrm{M}$ SA was applied (Ghasemzadeh et al., 2012). The optimal concentration of SA depends on the species and application method. In grapevine, the positive effects of exogenous $150 \mu \mathrm{M}$ SA on phenylpropanoid and flavonol biosynthesis have been investigated by in vivo incubation of the grape berry tissues in SA-containing medium (Chen et al., 2006; Fang and Huang, 2013). Here, we found that the application of $100 \mu \mathrm{M}$ SA in grape cell cultures could enhance flavonoid accumulation without affecting the regular growth of the cells. Of the concentrations, $100 \mu \mathrm{M}$ was chosen as the optimal concentration for SA elicitation in grape cell suspension cultures, which was consistent with the results reported by Obinata et al. (2003) and Xu et al. (2015).

It has been suggested that SA could enhance total flavonoid content in many plants (Chen et al., 2006; Dokhanieh et al., 2013; Ghasemzadeh et al., 2012; Pacheco et al., 2013; Thiruvengadam et al., 2015). The view was also confirmed in the present work. Salicylic acid induced the accumulation of flavonoids, particularly at $2 \mathrm{~d}$ after SA application (Fig. 3). We also observed that 
SA promoted the synthesis of total anthocyanins and PAs in grape cell cultures at different time courses. Our results are consistent with those of Ghasemzadeh et al. (2012) and López-Orenes et al. (2013) who reported SA-induced anthocyanin accumulation in ginger and PA content in Cistus, respectively. However, the positive effects of SA on total anthocyanin and PA accumulation were not synchronous (Fig. 3). The significantly increased total anthocyanin production in grape cell suspension cultures treated with SA was observed at $2 \mathrm{~d}$ after application, whereas the total PA content was enhanced at the later SA-treated stage (Fig. 3). When the anthocyanin content decreased after $2 \mathrm{~d}$ of incubation, the content of total PAs increased gradually until $8 \mathrm{~d}$ after incubation. This result might be related to the different branches of anthocyanin and PA biosynthesis. Although Griesser et al. (2008) have pointed out that there is a competition for common substrate between the different branches of flavonoids, the specific competition and regulation mechanism need to be made clear further.

Increasing information suggests that exogenous SA induces gene expression of $P A L$, 4CL (Ahn et al., 2014; Chen et al., 2006), STS (Xu et al., 2015), CHS, and CHI (Ahn et al., 2014; Sun et al., 2012), which in turn provokes the accumulation of phenylpropanoids, stilbenes, and some flavonoid compounds. In the present study, treatment of SA in grape cell cultures also markedly enhanced transcript accumulation of $\mathrm{VvCHS}$ and $\mathrm{VvCHI}$ in accordance with the changes in total flavonoid content (Fig. 4). In addition, the mRNA accumulation of two key later pathway genes $V v D F R$ and $V v A N S$ was induced by SA too (Fig. 4). These results indicate that increases in the gene transcripts of $V v C H S, V v C H I$, $V v D F R$, and $V v A N S$ may play an important role in the induction of anthocyanin and PA production by SA in grape suspension cells. Sun et al. (2012) have confirmed that SA can stimulate $F t$ CHS and FtDFR gene expression and cause rutin to accumulate in Fagopyrum tataricum leaves. Thiruvengadam et al. (2015) have demonstrated that the transcript levels of CHI and ANS genes increased after SA treatment in chinese cabbage. Previous studies have suggested that some transcription factor genes play important roles in regulating anthocyanin and PA biosynthesis, such as MYB-related genes in grape (Czemmel et al., 2012). Further studies on the effects of SA on these regulatory genes may deepen our understanding of the transcriptional regulation mechanism.

However, several studies have reported that the genes involved in flavonoid biosynthesis are regulated not only at the transcriptional level but also at the protein level (Chen et al., 2006; Wang et al., 2010, 2016). So, the effect of SA on the synthesis of new $V v \mathrm{CHS}$, $V v \mathrm{CHI}, V v \mathrm{DFR}$, and $V v \mathrm{ANS}$ proteins was investigated by western blotting assays. Compared with the controls, application of SA significantly increased $V v \mathrm{CHS}, V v \mathrm{CHI}, V v \mathrm{DFR}$, and $V v$ ANS protein amounts, particularly at
0.5-2 d after treatment (Figs. 5 and 6), which is consistent with the changes in the gene transcript level (Fig. 4). Treatment of the SA synthesis inhibitor Pac in grape cell suspension cultures inhibited the gene transcript and protein accumulation of $V v \mathrm{CHS}, V v \mathrm{CHI}, V v \mathrm{DFR}$, and VvANS (Figs. 4-6). These data suggest that SA may be involved in regulating the flavonoid metabolism of grape by inducing both transcript and protein accumulation of the corresponding enzymes. Wen et al. (2005) have shown that SA could induce the accumulation of $P A L$ mRNA and the synthesis of new PAL protein, which result in the increased accumulation of phenylpropanoids such as phenolic acids in grape berry (Chen et al., 2006). Fang and Huang (2013) have found that exogenous SA could modulate flavonol biosynthesis of grape berries by inducing new FLS protein and activating FLS activity at specific developing phases. Therefore, it is plausible that SA regulated the flavonoid metabolism at both the transcriptional and protein levels. But how SA affects the expression of flavonoid biosynthesis, and how the regulatory signals of SA are sensed and transmitted still need to be studied in the future.

In conclusion, the work presented here shows that the application of exogenous SA could actually induce the accumulation of mRNA, the synthesis of new proteins of flavonoid biosynthesis-related enzymes including $\quad V v \mathrm{CHS}, \quad V v \mathrm{CHI}, \quad V v \mathrm{DFR}$, and $V v \mathrm{ANS}$, and consequently enhance the accumulation of flavonoids such as anthocyanins and PAs. These results may provide useful theory evidences for the subsequent research work on how to improve the flavonoid contents of grape berries and wines.

\section{Literature Cited}

Ahn, S.Y., S.A. Kim, K.S. Cho, and H.K. Yun. 2014. Expression of genes related to flavonoid and stilbene synthesis as affected by signaling chemicals and Botrytis cinerea in grapevines. Biol. Plant. 58:758-767.

An, C. and Z. Mou. 2011. Salicylic acid and its function in plant immunity. J. Integr. Plant Biol. 53:412-428.

Bardford, M.M. 1976. A rapid and sensitive method for the quantitation of microgram quantities of protein utilizing the principle of proteinedye binding. Anal. Biochem. 72:248254.

Boss, P.K., C. Davies, and S.P. Robinson. 1996. Analysis of the expression of anthocyanin pathway genes in developing Vitis vinifera $\mathrm{L}$. cv Shiraz grape berries and the implications for pathway regulation. Plant Physiol. 111:10591066.

Buer, C.S. 2010. Flavonoids: New roles for old molecules. J. Integr. Plant Biol. 52:98-111.

Chen, J.Y., P.F. Wen, W.F. Kong, Q.H. Pan, J.C. Zhan, J.M. Li, S.B. Wan, and W.D. Huang. 2006. Effect of salicylic acid on phenylpropanoids and phenylalanine ammonia-lyase in harvested grape berries. Postharvest Biol. Technol. 40:64-72.

Czemmel, S., S.C. Heppel, and J. Bogs. 2012. R2R3 MYB transcription factors: Key regulators of the flavonoid biosynthetic pathway in grapevine. Protoplasma 249:109-118.

Dokhanieh, A.Y., M.S. Aghdam, J.R. Fard, and H. Hassanpour. 2013. Postharvest salicylic acid treatment enhances antioxidant potential of cornelian cherry fruit. Scientia Hort. 154:31-36. D'Onofrio, C., A. Cox, C. Davies, and P.K. Boss. 2009. Induction of secondary metabolism in grape cell cultures by jasmonates. Funct. Plant Biol. 36:323-338

Famiani, F., R.P. Walker, L. Tecsi, Z.H. Chen, P. Proietti, and R.C. Leegood. 2000. An immunohistochemical study of the comparmentation of metabolism during the development of grape berries. J. Expt. Bot. 51:675-683.

Fang, F. and W.D. Huang. 2013. Salicylic acid modulated flavonol biosynthesis in three key phases during grape berry development. Eur. Food Res. Technol. 237:441-448.

Flamini, R., F. Mattivi, M.D. Rosso, P. Arapitsas, and L. Bavaresco. 2013. Advanced knowledge of three important classes of grape phenolics: Anthocyanins, stilbenes and flavonols. Intl. J. Mol. Sci. 14:19651-19669.

Gamborg, O.L., R.A. Miller, and K. Ojima. 1968. Nutrient requirements of suspension cultures of soybean root cells. Expt. Cell Res. 50:151-158.

Georgiev, V., A. Ananga, and V. Tsolova. 2014. Recent advances and uses of grape flavonoids as nutraceuticals. Nutrients 6:391-415.

Ghasemzadeh, A., H.Z.E. Jaafar, and E. Karimi. 2012. Involvement of salicylic acid on antioxidant and anticancer properties, anthocyanin production and chalcone synthase activity in ginger (Zingiber officinale Roscoe) varieties. Intl. J. Mol. Sci. 13:14828-14844.

Griesser, M., T. Hoffmann, M.L. Bellido, C Rosati, B. Fink, R. Kurtzer, A. Aharoni, J. Munoz-Blanco, and S.W. Wilfried. 2008. Redirection of flavonoid biosynthesis through the down-regulation of an anthocyanidin glucosyltransferase in ripening strawberry fruit. Plant Physiol. 146:1528-1539.

Isla, M.I., M.A. Vattuone, and A.R. Sampietro. 1998. Essential group at the active site of Frapaeolum invertase. Phytochemistry 47:1189-1193.

Jeong, S.T., N. Goto-Yamamoto, S. Kobayashi, and M. Esaka. 2004. Effects of plant hormones and shading on the accumulation of anthocyanins and the expression of anthocyanin biosynthetic genes in grape berry skins. Plant Sci. 167:247-252.

Kennedy, J.A., G.J. Troup, J.R. Pilbrow, D.R. Hutton, D. Hewitt, C.R. Hunter, R. Ristic, P.G. Iland, and G.P. Jones. 2000. Development of seed polyphenols in berries from Vitis vinifera L. cv. Shiraz. Austral. J. Grape Wine Res. 6:244-254.

Kortekamp, A. 2006. Expression analysis of defence-related genes in grapevine leaves after inoculation with a host and a non-host pathogen. Plant Physiol. Biochem. 44:58-67.

Laemmli, U.K. 1970. Cleavage of structural protein during the assembly of the head bacteriophage T4. Nature 227:680-685.

León, J., V. Shulaev, N. Yalpani, M.A. Lawton, and I. Raskin. 1995. Benzoic acid 2-hydroxylase, a soluble oxygenase from tobacco, catalyzes salicylic acid biosynthesis. Proc. Natl. Acad. Sci. USA 92:10413-10417.

Liu, H.T., Y.Y. Liu, Q.H. Pan, H.R. Yang, J.C. Zhan, and W.D. Huang. 2006. Novel interrelationship between salicylic acid, abscisic acid, and PIP2-specific phospholipase $\mathrm{C}$ in heat acclimation-induced thermotolerance in pea leaves. J. Expt. Bot. 57:3337-3347.

Livak, K.J. and T.D. Schmittgen. 2001. Analysis of relative gene expression data using real-time quantitative PCR and the $2^{-\triangle \triangle C t}$ method. Methods 25:402-408.

López-Orenes, A., J.M. Martínez-Moreno, A.A. Calderón, and M.A. Ferrer. 2013. Changes in 
phenolic metabolism in salicylic acid-treated shoots of Cistus heterophyllus. Plant Cell Tissue Organ Cult. 113:417-427.

Matus, J.T., R. Loyola, A. Vega, A. Peña-Neira, E. Bordeu, P. Arce-Johnson, and J.A. Alcalde. 2009. Post-veraison sunlight exposure induces MYB-mediated transcriptional regulation of anthocyanin and flavonol synthesis in berry skins of Vitis vinifera. J. Expt. Bot. 60:853867.

Mustafa, N.R., W. De Winter, F. Van Iren, and R. Verpoorte. 2011. Initiation, growth and cryopreservation of plant cell suspension cultures. Nat. Protoc. 6:715-742.

Obinata, N., T. Yamakawa, M. Takamiya, N. Tanaka, K. Ishimaru, and T. Kodama. 2003. Effects of salicylic acid on the production of procyanidin and anthocyanin in cultured grape cells. Plant Biotechnol. 20:105-111.

Pacheco, A.C., C. da Silva Cabral, E.S. da Silva Fermino, and C.C. Aleman. 2013. Salicylic acid-induced changes to growth, flowering and flavonoids production in marigold plants. J. Med. Plants Res. 7:3158-3163.

Petrussa, E., E. Braidot, M. Zancani, C. Peresson, A. Bertolini, S. Patui, and A. Vianello. 2013. Plant flavonoids-biosynthesis, transport and involvement in stress responses. Intl. J. Mol. Sci. 14:14950-14973.

Reddy, A.M., V.S. Reddy, B.E. Scheffler, U. Wienand, and A.R. Reddy. 2007. Novel transgenic rice overexpressing anthocyanidin synthase accumulates a mixture of flavonoids leading to an increased antioxidant potential. Metab. Eng. 9:95-111.
Sun, Z., S. Hou, W. Yang, and Y.H. Han. 2012. Exogenous application of salicylic acid enhanced the rutin accumulation and influenced the expression patterns of rutin biosynthesis related genes in Fagopyrum tartaricum Gaertn leaves. Plant Growth Regulat. 68:9-15.

Thiruvengadam, M., S.H. Kim, and I.M. Chung. 2015. Exogenous phytohormones increase the accumulation of health-promoting metabolites, and influence the expression patterns of biosynthesis related genes and biological activity in Chinese cabbage (Brassica rapa spp. pekinensis). Sci. Hort. 193:136-146.

Tian, L., W.F. Kong, Q.H. Pan, J.C. Zhan, P.F. Wen, J.Y. Chen, S.B. Wan, and W.D. Huang. 2006. Expression of the chalcone synthase gene from grape and preparation of an anti-CHS antibody. Protein Expr. Purif. 50:223-228.

Tounekti, T., I. Hernández, and S. Munné-Bosch. 2013. Salicylic acid biosynthesis and role in modulating terpenoid and flavonoid metabolism in plant responses to abiotic stress, $\mathrm{p}$. 141-162. In: S. Hayat, A. Ahmad, and M.N. Alyemeni (eds.). Salicylic acid. Springer, Dordrecht, The Netherlands.

Wang, H.L., W. Wang, H. Li, J.C. Zhan, and W.D. Huang. 2011. Expression, tissue and subcellular localization of anthocyanidin synthase (ANS) in grapevine. Protoplasma 248:267279.

Wang, H.L., W. Wang, J.C. Zhan, W.D. Huang, and H.Y. Xu. 2015. An efficient PEG-mediated transient gene expression system in grape protoplasts and its application in subcellular localization studies of flavonoids biosynthesis enzymes. Scientia Hort. 191:82-89.
Wang, H.L., W. Wang, J.C. Zhan, A.L. Yan, L. Sun, G.J. Zhang, X.Y. Wang, J.C. Ren, W.D. Huang, and H.Y. Xu. 2016. The accumulation and localization of chalcone synthase in grapevine (Vitis vinifera L.). Plant Physiol. Biochem. 106:165-176.

Wang, H.L., W. Wang, P. Zhang, Q.H. Pan, J.C. Zhan, and W.D. Huang. 2010. Gene transcript accumulation, tissue and subcellular localization of anthocyanidin synthase (ANS) in developing grape berries. Plant Sci. 179:103-113.

Wang, W., H.L. Wang, S.B. Wan, P. Zhang, J.C. Zhan, and W.D. Huang. 2012. Chalcone isomerase gene from grape berry: CDNA cloning, tissue expression, and immunohistochemical localization. Biol. Plant. 56:545-550.

Wen, P.F., J.Y. Chen, W.F. Kong, Q.H. Pan, S.B. Wan, and W.D. Huang. 2005. Salicylic acid induced the expression of phenylalanine ammonia-lyase gene in grape berry. Plant Sci. 169:928-934.

Wolfe, K., X. Wu, and R.H. Liu. 2003. Antioxidant activity of apple peels. J. Agr. Food Chem. 51:609-614.

Xu, A., J.C. Zhan, and W.D. Huang. 2015. Effects of ultraviolet $\mathrm{C}$, methyl jasmonate and salicylic acid, alone or in combination, on stilbene biosynthesis in cell suspension cultures of Vitis vinifera L. cv. Cabernet Sauvignon. Plant Cell Tissue Organ Cult. 122:197-211.

Zhang, P., P.F. Wen, S.B. Wan, W. Wang, Q.H. Pan, J.C. Zhan, and W.D. Huang. 2008. Molecular cloning of dihydroflavonol 4-reductase gene from grape berry and preparation of an anti-DFR polyclonal antibody. Vitis $47: 141-$ 145 . 


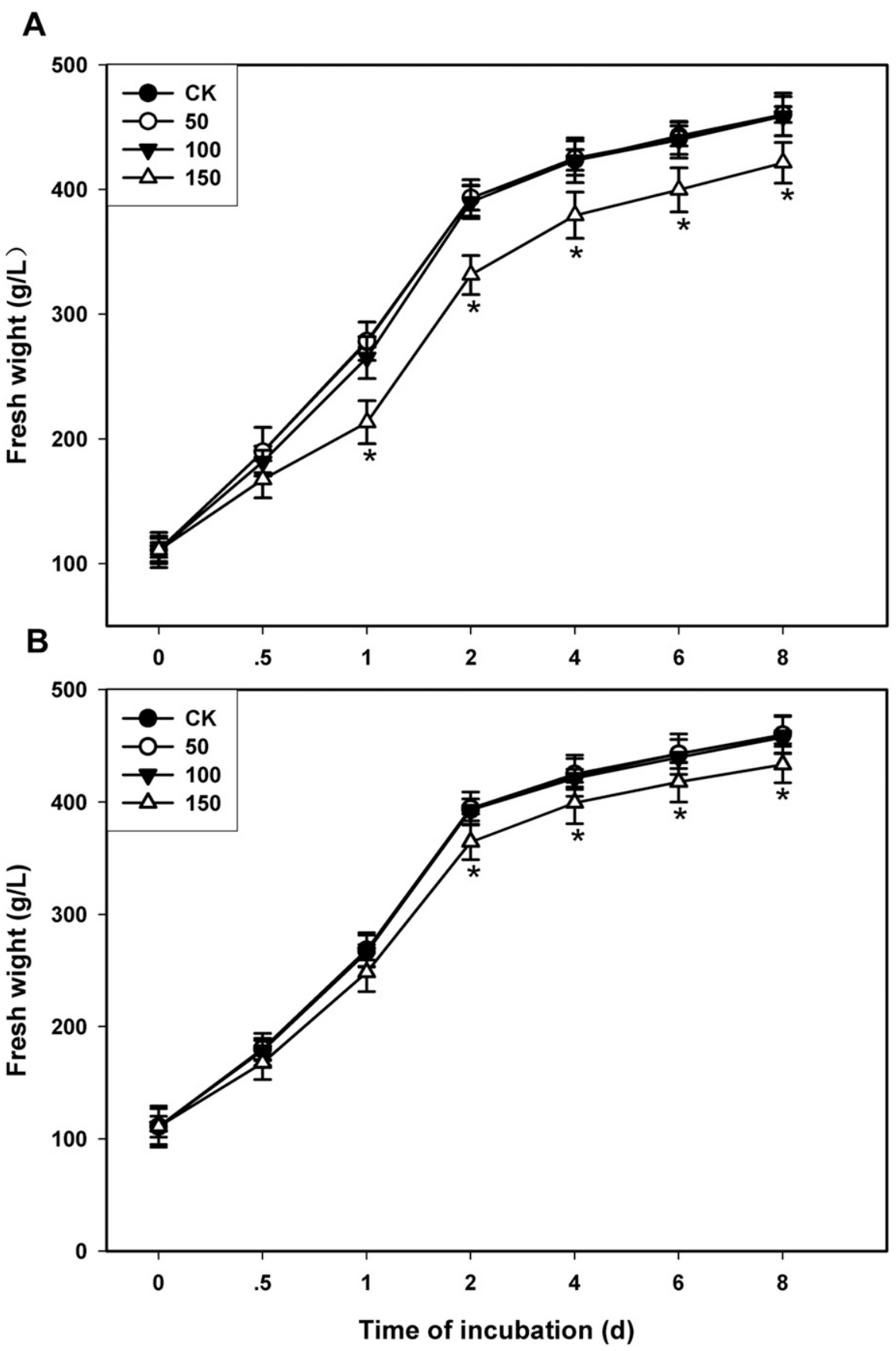

Supplemental Fig. 1. Growth curves of control (CK) and treated $V$. vinifera cell cultures with different concentrations $(50 \mu \mathrm{M}, 100 \mu \mathrm{M}$, and $150 \mu \mathrm{M})$ of SA (A) and Pac (B). *Statistically significant difference (Student's $t$ test, $P \leq 0.05$ ) between cells under elicitation and control cells at each time point. Values are mean $\pm \operatorname{SE}(n=3)$. 
A
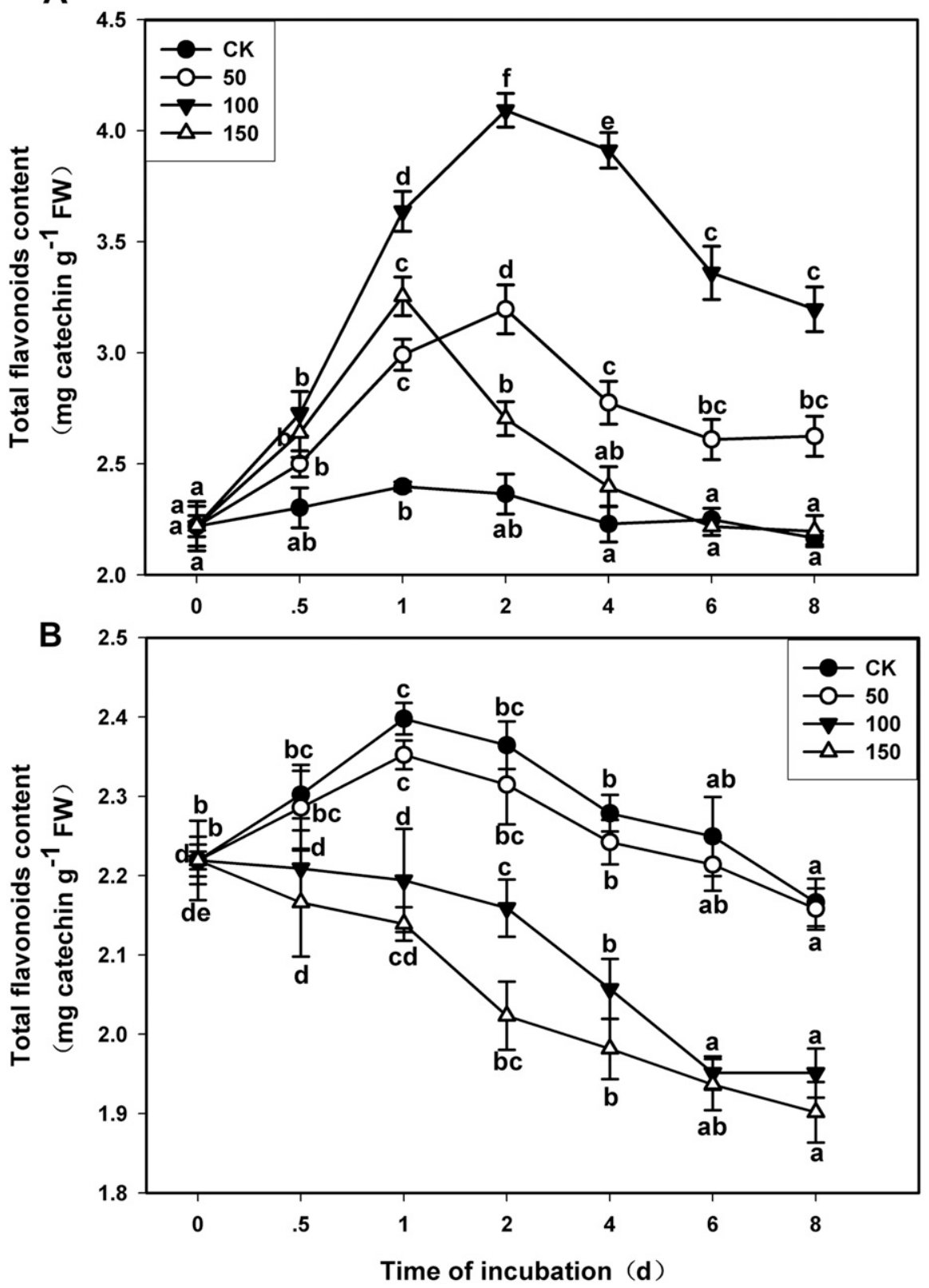

Supplemental Fig. 2. The changes of total flavonoids content in control (CK) and treated grape berry suspension cells by different concentrations $(50 \mu \mathrm{M}, 100 \mu \mathrm{M}$, and $150 \mu \mathrm{M})$ of SA and Pac. (A) The effect of different concentrations of SA on total flavonoids content. (B) The effect of different concentrations of Pac on total flavonoids content. Different letters indicate a statistical difference at $P \leq 0.05$ among samples according to Duncan's multiple range tests.

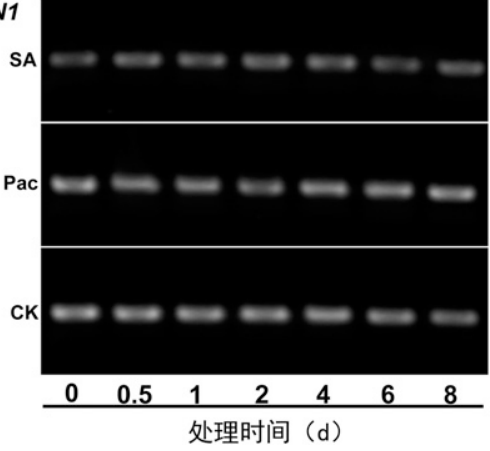

Supplemental Fig. 3. Effects of SA and PAC on the accumulation gene transcript of constitutive expression gene VvActinl in grape berry suspension cell cultures. 


\begin{tabular}{|c|c|c|c|c|c|}
\hline Genes & Primer sequence $\left(5^{\prime}-3^{\prime}\right)$ & $\begin{array}{l}\text { Expected size o } \\
\text { f PCR product (bp) }\end{array}$ & $\begin{array}{c}\text { Accession } \\
\text { number (NCBI) }\end{array}$ & Annealing temp $\left({ }^{\circ} \mathrm{C}\right)$ & Optimized PCR cycles \\
\hline $\mathrm{VvCHI}$ & $\begin{array}{l}\text { Forward: 5' -GCGGATTCGGTTGACTTTTT-3' } \\
\text { Reverse: 5'-CTGGTAGGGACCCATCTTTG-3' }\end{array}$ & 292 & X75963 & 47 & 23 \\
\hline$V v D F R$ & $\begin{array}{l}\text { Forward: 5' -CCCCGATCACTGGAAACGAAG-3' } \\
\text { Reverse: } 5^{\prime} \text {-ATGTGAAGGGCGAAGCAATCC-3' }\end{array}$ & 356 & X75964 & 53 & 29 \\
\hline$V v A N S$ & $\begin{array}{l}\text { Forward: 5' -AGGGCCTCAGGTTCCAACTAT-3' } \\
\text { Reverse: } 5^{\prime} \text {-CTCCCACTCAAGCTGTCCACT-3' }\end{array}$ & 292 & EU156063 & 51 & 26 \\
\hline
\end{tabular}

Supplemental Table 2. Primers used for the quantification of gene expression levels by qRT-PCR.

\begin{tabular}{|c|c|c|c|c|}
\hline Gene name & Accession number & Primer & Sequence $\left(5^{\prime} \rightarrow 3^{\prime}\right)$ & Reference \\
\hline$\overline{V v C H S}$ & $\mathrm{AB} 015872$ & $\mathrm{~F}$ & CGATAGGCATCAGCGACT & Xu et al. (2015) \\
\hline & & $\mathrm{R}$ & TTTTCCTCATTTCGTCCAG & \\
\hline $\mathrm{VvCHI}$ & X75963 & $\mathrm{F}$ & CAGGCAACTCCATTCTTTTC & Jeong et al. (2004) \\
\hline & & $\mathrm{R}$ & TTCTCTATCACTGCATTCCC & \\
\hline$V v D F R$ & X75964 & F & GAAACCTGTAGATGGCAGGA & Jeong et al. (2004) \\
\hline VvANS & X75966 & $\begin{array}{l}\mathrm{R} \\
\mathrm{F} \\
\mathrm{R}\end{array}$ & $\begin{array}{l}\text { GGCCAAATCAAACTACCAGA } \\
\text { AGGGAAGGGAAAACAAGTAG } \\
\text { ACTCTTTGGGGATTGACTGG }\end{array}$ & Jeong et al. (2004) \\
\hline VvActinl & AY680701 & $\begin{array}{l}\mathrm{F} \\
\mathrm{R}\end{array}$ & $\begin{array}{l}\text { CTACTGCTGAACGGGAAAT } \\
\text { ACTTCTGGACAACGGAATC }\end{array}$ & Xu et al. (2015) \\
\hline
\end{tabular}

qRT-PCR $=$ quantitative real-time polymerase chain reaction; $V v C H S=$ chalcone synthase; $V v C H I=$ chalcone isomerase; $V v D F R=$ dihydroflavonol 4-reductase; $V v A N S=$ anthocyanidin synthase. 